\title{
上海市超高層複合施設のコージェネレーションシステムの導入における 省エネルギー効果の評価及び影響因子の感度分析 SENSIBILITY ANALYSIS OF INFLUENCING PARAMETERS OF ENERGY SAVING EFFECT BY INTRODUCING A CO-GENERATION SYSTEM IN A SKYSCRAPER COMPLEX IN SHANGHAI
}

\author{
玄 姫*, 高 偉 俊**, 韋 新 東***, 李 海 峰****, 堤 洋 樹***** \\ Ji XUAN, Weijun GAO, Xindong WEI, \\ Haifeng LI and Hiroki TSUTSUMI
}

\begin{abstract}
In this paper, a proposed co-generation system (CGS) for a skyscraper complex building (JM Tower) in the centre of Shanghai has been evaluated. Two types of energy supply systems are considered: electricity-only and CGS. Compared with a conventional system, the CGS is capable of reducing the primary energy consumption by $29.94 \%$ per year. Sensitivity analysis about energy saving ratios is carried out in this paper to study influencing parameters, such as unit capacity, generator's scales and efficiency, partial load, increase-decrease rate of fuel charge. It is shown in result that different influencing parameters have different weight in energy saving ratio, and the power generation efficiency of CGS is the most important influencing parameter on energy saving ratio.
\end{abstract}

Keywords : Shanghai, Skyscraper complex building, Co-generation (CGS), Energy saving, Influencing parameter, Sensibility analysis

上海市，超高層複合施設，コージェネレーションシステム (CGS)，省エネルギー性， 影響要因, 感度分析

\section{1. はじめに}

近年では、経済の急速な発展と生活レベルの向上に伴い、中国の 一人当たりの年間エネルギー消費量は年々増加する傾向になってお り、2001 年における中国の一次エネルギー総消費量は 13.2 億 Tce （標準炭換算 1 Tce=29.31 GJ）に達し1）、アメリカに次ぐ世界第二 のエネルギー消費大国となり、世界のエネルギー消費量の約 $11 \%$ ま で占めるようになった。一方、中国のエネルギー構造は約 7 割を石 炭に依存しているため、石油資源が欠乏し、今後のエネルギー消費 量の増加と環境保護の矛盾は日々顕著になり、急速な経済成長に伴 うエネルギー資源の相対的な不足も中国経済及び社会の持続可能な 発展にとって大きいなボルトネックになることは明らかである。

現在、上海のような大都市部におけるこのようなローカルな環境 問題とグローバルな環境問題を同時に解決するには、従来の石炭依 存のエネルギー供給システムから、コージェネレーションシステム （以下、CGS と略記する）のようなクリーンかつ高効率な省エネル ギーシステムへの転換は急務である。これまで上海市におけるエネ ルギー事情、省エネ技術の導入検討に当たって、工場、病院や空港、 娛楽センターにおける CGS 導入ケースはいくつが見られたが2)、才 フィスビルやホテル等を対象とする CGS の導入事例がまだないため、 その導入効果をより定量的に把握することは重要であり、今後の中
国国内における CGS の推進と普及にとって大きな意味を持つと考え られる。

このような背景を踏まえ、本研究は世界に注目されている大都市 である中国上海市を対象に、近年では急速に普及し始めた超高層複 合施設のエネルギー消費状況を調査し、CGS の導入を模索する。研 究対象である上海市の Jim Mao Tower（以下 JM ビルと略記する）で は、現在上海市金茂（集団）股分有限公司が当該ビルのエネルギー 使用を管理・運営しており、そのうち、ホテル、キッチン以外の部 分を対象に、インテリジェント照明システム等の導入を通じて、省 エネルギー効果を向上させている。また、当該ビルに銀行等の金融 機関が多く入居しているため、近年の電力不足の状況にあっても、 停電しないように電力が優先的に供給されている。当該ビルのエネ ルギーセンター管理者の話によると、2010 年の上海万博会へ向け、 上海市では CGS、地域冷暖房システムの導入、また分散型発電シス テム、氷蓄熱システムの導入を推奨しており、当該ビルにもCGS の 導入を積極的に試みたいという。

日本では、CGS に関しては多くの研究が行われている。市川ら ${ }^{3)}$ 大規模住宅団地における CGS 導入の可能性に関寸る研究を行った。 三瀬ら ${ }^{4)}$ はキャンパスにおける CGS の省エネルギー性および環境性 を評価した。村上ら ${ }^{5}$ は集合住宅と高齢者福祉施設の複合建物にお

\footnotetext{
$*$ 北九州市立大学大学院 大学院生·工修

* 北九州市立大学・西安交通大学・吉林建築工程学院 教授. 工博

*** 吉林建築工程学院 教授. 工博

**** 佐賀大学理工学部 准教授 $\cdot$ 工博

***** 九州共立大学 准教授.工博

Graduate Student, The Univ. of Kitakyushu, M. Eng.

Prof., The Univ. of Kitakyushu, Xi'an Jiaotong Univ., Jilin Archit. and Civil Eng. Institute, Dr. Eng.

Prof., Jilin Archit. and Civil Eng. Institute, Dr. Eng.

Assoc. Prof., Saga Univ., Dr. Eng.

Assoc. Prof., Kyushu Kyoritsu Univ., Dr. Eng.
} 
けるコージェネレーションシステムの効果を検討した。岡ら ${ }^{6)}$ は CGS を導入した病院施設のライフサイクル評価等を行った。 また、近年では佐土原ら ${ }^{7)}$ 、村上ら ${ }^{8)}$ 、柳井ら ${ }^{9)}$ は地域熱供給に おける CGS を含めた分散型エネルギー供給システムの研究が多 く行っている。内山ら ${ }^{10)}$ は分散型電源システムの発電コストを 検討寸る際、割引率の変化が発電コストに与える影響を感度解 析した。ホテルやオフィスを含めた複合施設への CGS 導入研究 がまだ少ない。

中国の CGS 研究では、岡田らは11)、中国広州市における次世 代エネルギーシステム評価のための都市モデル構築に関する基 礎的検討を行う時、日本の代表的な民生部門負荷パターンに基 づき、気温との相関により、広州市における負荷パターンの推 定を試み、CGS 評価プログラムを用いて試算した。また、安芸 $ら^{12)}$ は文献調查や専門家への聞き取り調查を基に、中国の都市 部における天然ガスによる建物 CGS の現状や政策的、経済的及 び技術的課題並びに将来見通しについて分析し、感度分析を用 い経済性のみを検討した。

以上の背景から、本研究ではまず収集した JM ビルの 2006 年 の各種エネルギー消費量データを基に、複合施設の電力・熱負 荷の特性を解析したうえ、既存システムに対寸る一次エネルギ 一削減効果の評価から CGS の導入可能性を検討する。また、重 回帰分析法を用い、省エネルギー性への影響因子と考えられる 要因変化 (発電機の単機容量の規模、発電機の効率、発電機の台 数、部分負荷、燃料料金の増減)について総合的な感度分析を行 う。

\section{2. 実態調査 \\ 2.1 調査概要}

JM ビルの外観と平面図を図 1 に示す。JM ビルは 1998 年に竣 工され、地上 88 階、現在世界第 4 位の高さ $(420.5 \mathrm{~m})$ を誇る中 国を代表する建物である。

調査項目は建物概要、設備概要、空調設備容量、エネルギー 消費量及び省エネルギーに対するビル側の認識や、その取り組 み等をヒアリングした (表 1)。建物階数別の主な用途別建物之 して、3〜50 階はオフィス (約 130, $\left.000 \mathrm{~m}^{2}\right) 、 53 \sim 87$ 階はホテル (約 70,000 $\mathrm{m}^{2}$ )である。

\section{2 受電設備及び空調設備}

現状の JM ビルの電力消費はすべて系統電力によって賄われ、 受電電圧は $6.6 \mathrm{kV}$ である。複合施設である当ビルは、通年に渡 って冷水と温水が必要であるため、冷水を用いた泠房運転と温 水を用いた暖房運転を同時に行う事ができる 4 管式を採用して いる。冷熱供給では、遠心式冷凍機の容量が 1200 USRT (1 USRT=3. $5 \mathrm{~kW})$ の 6 台と 400 USRT の 2 台、計 8 台を低層と高層 にそれぞれ 4 台ずつ設置され、冷房需要を賄っている。また、 57 階以下または 86 階からビルの最高階までには変風量全空気 システムがあり、58 階から 85 階ではファンコイルと外気取り 入れ制御システムが設置されている。一方、暖房需要に対して ボイラーから熱交換器、ポンプ、空気調和機、ファンコイルを 通じて供給されている。給湯は温水発生器を通じて賄われてい

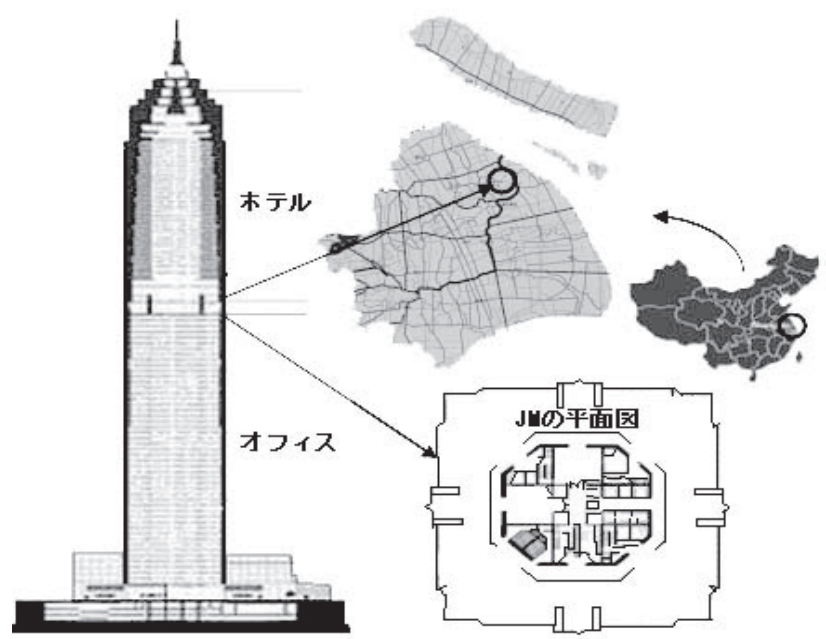

図 1 研究対象の外観と平面図

表 1 調查項目

\begin{tabular}{|c|}
\hline $\begin{array}{l}\text { (1) 建物概要 } \\
\text { 各フロアの用途、延べ床面積、階数、在館人員、客室数(ホテル)、竣工年、契約 } \\
\text { 電力、冷暖房負荷設計值 }\end{array}$ \\
\hline \begin{tabular}{|l|l|} 
(2) 設備概要 \\
電気設備・空調方式
\end{tabular} \\
\hline 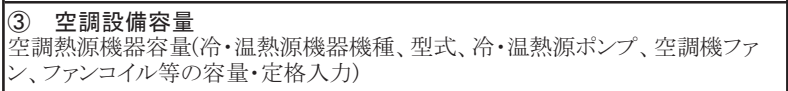 \\
\hline $\begin{array}{l}\text { 空調動力容量 } \\
\text { (冷却塔ファン、冷却水ポンプ、冷・温熱ポンプ、空調機ファン、ファンコイル等の容 } \\
\text { 量・定格入力) }\end{array}$ \\
\hline \begin{tabular}{|l|} 
(4) エネルギー消費量 \\
電力、天然ガス、油、水の消費量 \\
\end{tabular} \\
\hline \begin{tabular}{|l} 
(5) エネルギー種別の使途 \\
泠房、暖房、給湯、厨房、プール加湿、殺菌、消毒、非常用発電機、その他
\end{tabular} \\
\hline
\end{tabular}

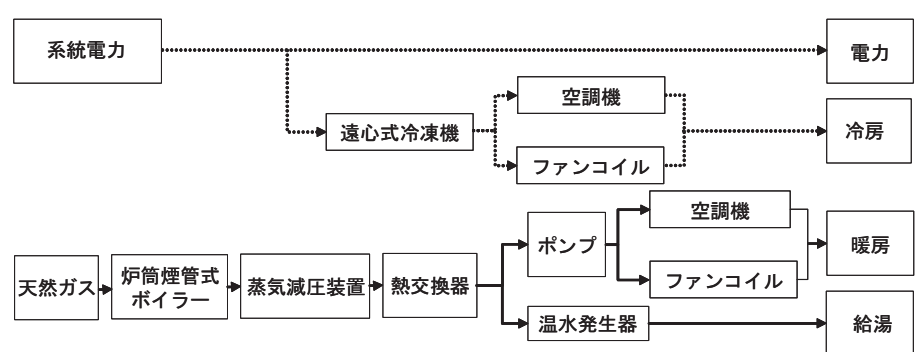

図 2 既存システムのフロー

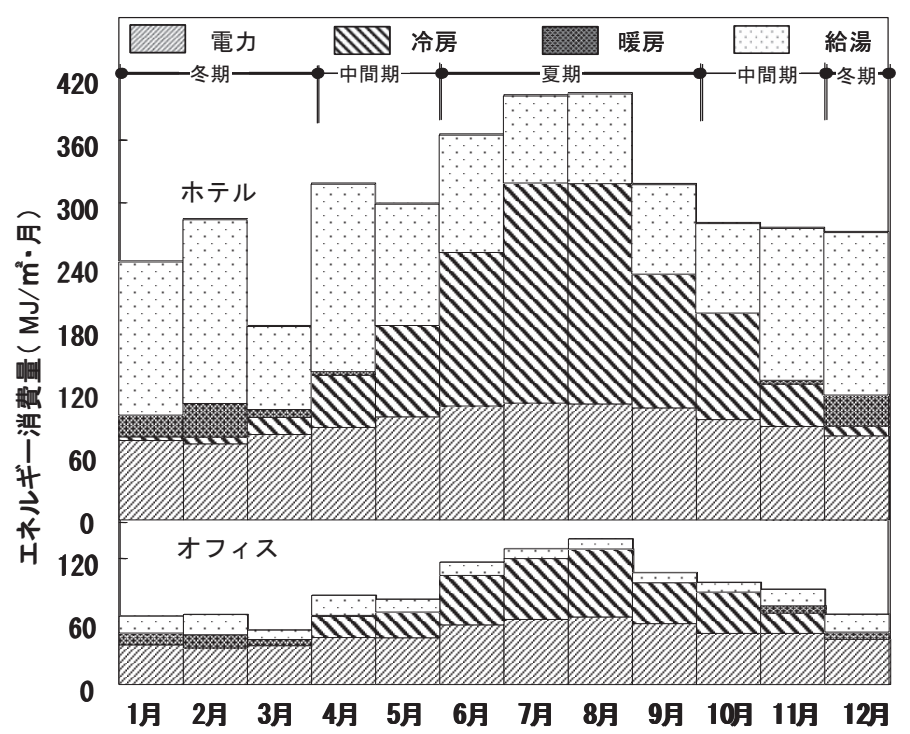

図 3 延べ床面積当たりの月別各種エネルギー消費量 


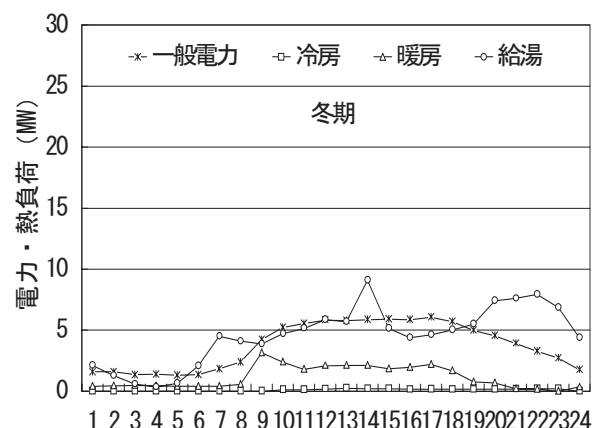

(a) 冬期 (1月)

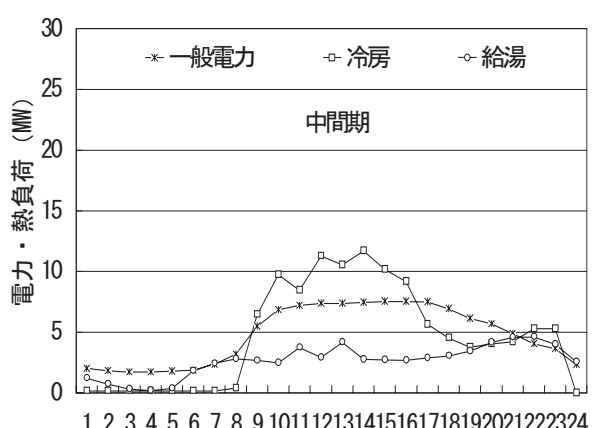

(b) 中間期 (5 月)

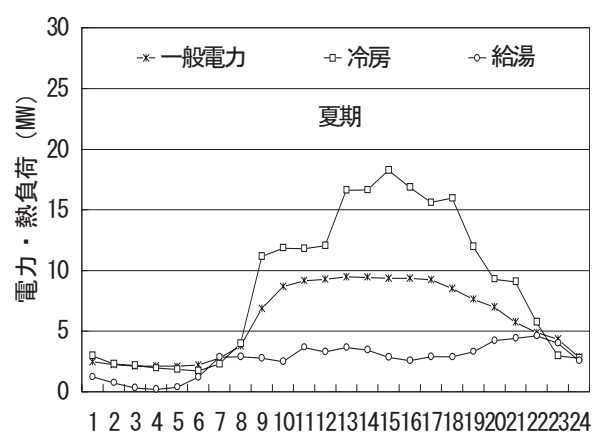

(c) 夏期 (8 月)

図 4 各季節の時刻別電力・熱負荷

る(図 2)。

\section{3 エネルギ一消費量の分析}

図 3 に建物用途別における月別の各種エネルギー消費量を示す。 季節ごとから見ると、夏期では大きい山ができ、全体の $50 \%$ 近く占 めている。延心゙床面積当たりの年間のエネルギー消費量の中、一般 電力が最も高く (オフィス：557 $\mathrm{MJ} / \mathrm{m}^{2}$ 、ホテル：1112 $\mathrm{MJ} / \mathrm{m}^{2}$ )、次に 給湯 (オフィス : $151 \mathrm{MJ} / \mathrm{m}^{2}$ 、ホテル : $1435 \mathrm{MJ} / \mathrm{m}^{2}$ )、冷房 (オフィス : $300 \mathrm{MJ} / \mathrm{m}^{2}$ 、ホテル : $1002 \mathrm{MJ} / \mathrm{m}^{2}$ )、及び暖房 (オフィス : $43 \mathrm{~mJ} / \mathrm{m}^{2}$ 、 ホテル： $96 \mathrm{MJ} / \mathrm{m}^{2}$ )の順となる。建物用途別の各種エネルギー消費量 から見ると、ホテルが全体の 6 割以上を占めている。その中、給湯 の割合はホテル全体エネルギー消費の $71 \%$ ありり、給湯消費量がか なり高いことから、洗濯やシャワーなどに大量のお湯が使われてい ると考えられる。

\section{4 時刻別負荷特性に対する考察}

CGS 導入可能性を検討するに当たって、JM ビ ルの時刻別負荷特性の分析は重要である。ここ では当該ビルの冬期 (1月)、中間期 (5 月)、夏期 （8月）の代表平日の 24 時間の一般電力、冷暖 房及び給湯負荷を図 4 の a c に示す。これらの 結果から次の特徵が得られた。

(1) 一般電力負荷はいずれの季節でも全時間 帯を通じて一定になっており、夏期の負荷 が他の季節より大きいが、それぞれのパタ ーンはほぼ一致している。

(2) 冷房負荷は 7 時から 22 時までに山ができ、 夏期の午後 3 時頃にピークを迎え、大きい なばらつきが見られる。また、夜間の間も 一定の負荷があり、これは、ホテルに宿泊 する人が多く、夜間も冷房をつけたままで 就寝していること等の原因が考えられる。 全時間帯を通じて一般電力負荷と比べ、冷 房負荷の変化幅が大きいことが分かる。

(3) 暖房負荷が小さい。その原因として、上海 市の気候、当該ビルの高気密構造及び内部 発熱等の要因が考えられる。

(4) ホテルの給湯負荷は年中高く占め、22 時以

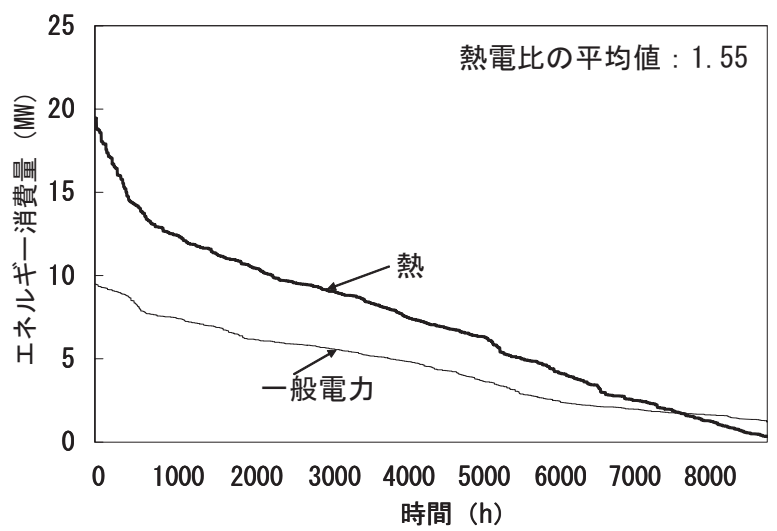

図 5 熱電比

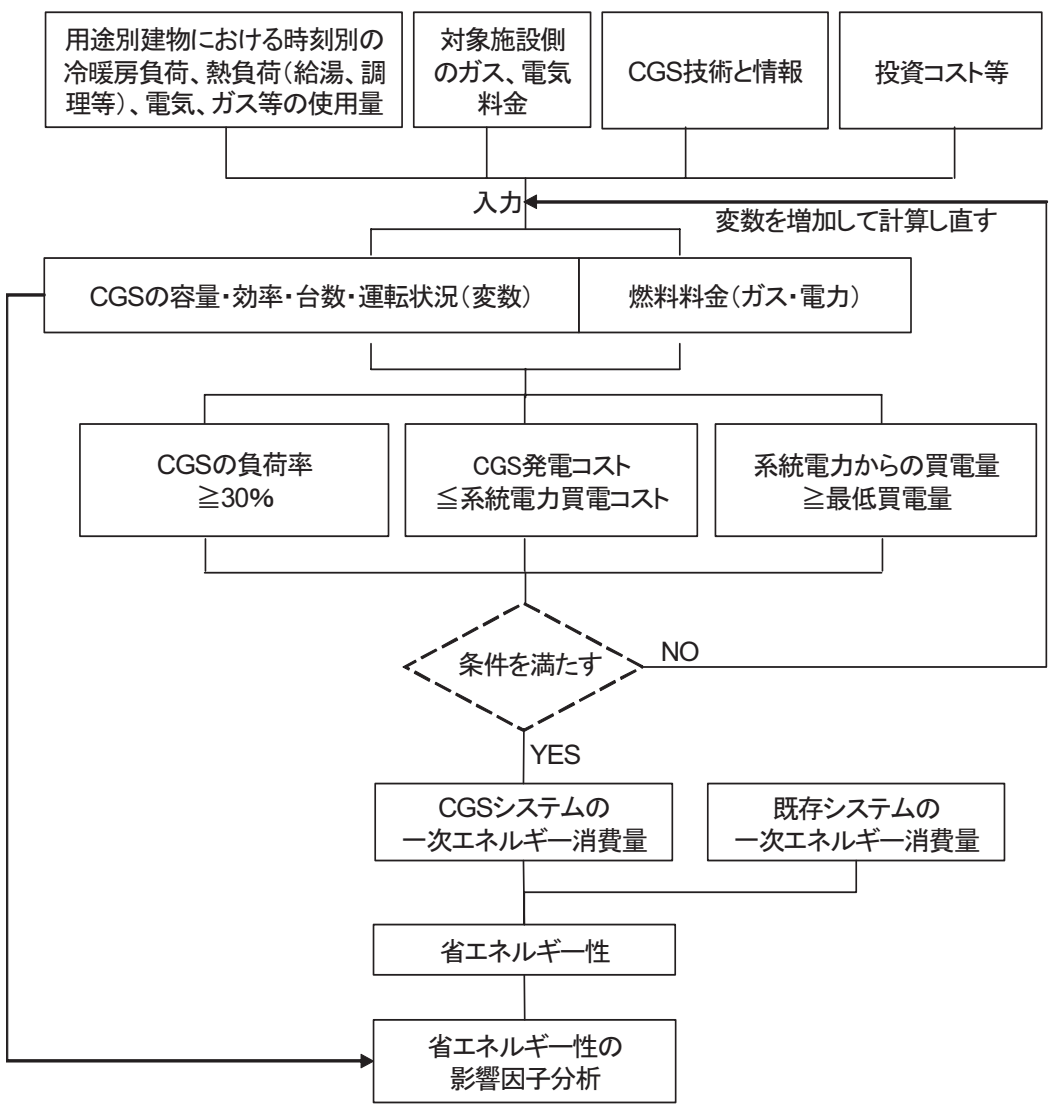

図 6 シミュレーションの流れ 
降になってもその消費量が非常に高い。

また、熱需要と一般電力需要の累積曲線（図 5）を見ると、温熱 需要量が一般電力需要量を上回っている。CGS のエネルギー利用評 価には、建築物の熱需要と電力需要のバランスが非常に重要である。 年間 8760 時間の温熱消費量と一般電力消費量の比率 (熱電比)を算 出し、最大值は 3.72 であり、平均值は 1.55 に達している。

\section{CGS 導入のシミュレーション手法}

\section{1 研究流れ}

図 6 にシミュレーションの流れを示す。先ず、上述の時刻別熱・ 電力負荷の特性を入力し、CGS の容量、効率、運転状況及び然料料 金等を設定し、筆者ら ${ }^{13)}$ が開発した CGS エネルギー計算手法を用い て、一定の制約条件の下に CGS を導入したシステムの一次エネルギ 一消費量を計算する。計算された一次エネルギー消費量を既存シス テム（図 2）の一次エネルギー消費量と比較し、その省エネルギー 率を以下の式により分析する。

$\eta_{\Delta E}^{C G S}=\frac{Q_{E}^{\text {Conv }}-Q_{E}^{C G S}}{Q_{E}^{\text {Conv }}}=\frac{\left(Q_{\text {Gas }}^{\text {Conv }}+\frac{Q_{\text {Power }}^{\text {Conv }}}{\eta_{E}^{\text {Utility }}}\right)-\left(Q_{\text {Gas }}^{\text {CGS }}+\frac{Q_{\text {Power }}^{\text {Utility }}}{\eta_{E}^{\text {Utility }}}\right)}{\left(Q_{\text {Gas }}^{\text {Conv }}+\frac{Q_{\text {Power }}^{\text {Conv }}}{\eta_{E}^{\text {Utility }}}\right)}$

ここでは、

$\eta_{\Delta E}^{C G S}=\mathrm{CGS}$ システムの省エ ネルギー率(一次エネ ルギ削減率)

$Q_{E}^{C o n v}=$ 既存システムの一次エ ネルギー消費量 $\quad \mathrm{MJ}$

$Q_{E}^{C G S}=\mathrm{CGS}$ システムの一次 エネルギー消費量 $\mathrm{MJ}$

$Q_{G a s}^{C o n v}=$ 既存システムのガスエ ネルギー消費量 $\mathrm{MJ}$

$Q_{\text {Power }}^{\text {Conv }}=$ 既存システムの商用電 力消費量 $\mathrm{MJ}$

$Q_{\text {Gas }}^{C G S}=\mathrm{CGS}$ システムのガス エネルギー消費量 $\mathrm{MJ}$

$Q_{\text {Power }}^{\text {Utility }}=$ CGSシステムの商用 電力消費量 (買電によ る電力消費量) $\quad$ MJ

$\eta_{E}^{\text {Uility }}=$ 商用電力の発電効率 （中国の場合、約 $33.25 \%{ }^{12}$ )

また計算では、CGS の導入に関しては、表 2 に示すように評価項 目を設定し、変数として、システムの一次エネルギー消費量を試算 する。分析では、まず CGS の容量（規模）による省エネルギー性一 の影響を分析する。経済性とあわせて、CGS 導入の適切な発電容量 （規模）を確定する。選択されたCGS 発電容量に対して、発電機の 発電効率と熱回収効率を変化した場合、省エネルギー率への影響を 分析する。さらに台数制御によるシステムの省エネルギー性への影 響を検討する。CGS 発電機の規模、効率及び台数が確定されたとこ ろ、運転時において、燃料料金の省エネルギー性への影響を探るこ とにする。

経済性を分析するときには、ライフサイクルコスト ${ }^{14)}$ を用いて下 記の式で計算する。

$$
M(n)=\left(C_{0}+\sum_{j=1}^{n} \frac{E_{j}}{(1+i)^{j}}\right) \times\left(\frac{i(i+1)^{n}}{(i+1)^{n}-1}\right)
$$

ここでは、

$$
\begin{aligned}
M(n) & =\mathrm{LCC} \text { 平均年間コスト 円 } \\
C_{0} & =\text { 初期投资 } \mathrm{A} \\
E_{j} & =\text { 使用年数 } \mathrm{j} \text { 年目のラン ニングコスト 円 } \\
n & =\text { 使用年数 年 } \\
i & =\text { 金利 } \% \text { 今では } 2.5 \% \text { とする) }
\end{aligned}
$$

\begin{tabular}{|c|c|c|}
\hline 評価視点 & 評価項目 & 変化範囲 \\
\hline \multirow{4}{*}{ 省エネルギー率 } & 単機容量の規模 & 最大電力需要量の10\%〜100\% \\
\hline & 発電効率·排熱効率 & $\begin{array}{l}\text { 発電効率：25\%～40\% } \\
\text { 熱回収効率：40\%、45\% }\end{array}$ \\
\hline & 台数 & 1 4台 \\
\hline & 燃料単価の増減 & $\begin{array}{l}\text { 電力：現行料金の } 100 \% \text { と } 50 \% \\
\text { ガス：現行料金の- } 60 \% \text { 140\% }\end{array}$ \\
\hline
\end{tabular}

\begin{tabular}{|c|c|c|c|c|}
\hline & \multicolumn{2}{|c|}{ 運転形態 } & CGS導入率※ & CGS初期投資 (円 $/ \mathrm{kW}$ ) \\
\hline \multirow{7}{*}{ a. } & \multicolumn{2}{|c|}{ 電主熱従（逆潮なし） } & $10 \%$ & 212,500 \\
\hline & 原動機 & ガスタービン & $20 \%$ & 200,110 \\
\hline & 電力需要のピーク値 & $9470 \mathrm{~kW}$ & $30 \%$ & 197,500 \\
\hline & 発電機最高負荷率 & $100 \%$ & $40 \%$ & 191,670 \\
\hline & 発電機最低負荷率 & $30 \%$ & $50 \%$ & 186,250 \\
\hline & 補機動力消費量 & $5 \%$ & $60 \%$ & 181,250 \\
\hline & $\begin{array}{l}\text { 最小買電量 } \\
\end{array}$ & $10 \%$ & $70 \%$ & 177,500 \\
\hline & \multicolumn{2}{|c|}{ 機器効率 } & $80 \%$ & 172,500 \\
\hline \multirow{6}{*}{ b. } & CGS発電効率※ & $25-40 \%$ & $90 \%$ & 165,000 \\
\hline & CGS熱回収効率 & $40,45 \%$ & $100 \%$ & 163,750 \\
\hline & 系統電力の発電効率 & $33.25 \%$ & \multicolumn{2}{|c|}{ 他設備の単価 (円/kW) } \\
\hline & 吸収式冷凍機COP & 1.1 & 遠心式冷凍機 & 6,621 \\
\hline & 熱交換器COP & 1.0 & $d$ 吸収式冷凍機 & 18,043 \\
\hline & ボイラー & $85 \%$ & ボイラー & 1,814 \\
\hline & & & 熱交換器 & 2,100 \\
\hline \multirow{6}{*}{ e. } & エネルギー & & 価格 & \\
\hline & \multirow{4}{*}{ 電力（円/kWh） } & ピーク & 準ピーク & その他 \\
\hline & & $8: 00 \mathrm{~h}-11: 00 \mathrm{~h}$ & $6: 00 \mathrm{~h}-8: 00 \mathrm{~h}$ & 22:00h-6:00h \\
\hline & & 18:00h-22:00h & 11:00h-18:00h & \\
\hline & & 16.09 & 11.39 & 5.93 \\
\hline & 天然ガス (円/m3) & \multicolumn{3}{|c|}{30} \\
\hline \multicolumn{5}{|c|}{ 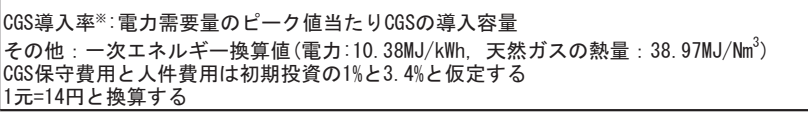 } \\
\hline
\end{tabular}

表 2 評価項目

表 3 各種パラメーターの設定值

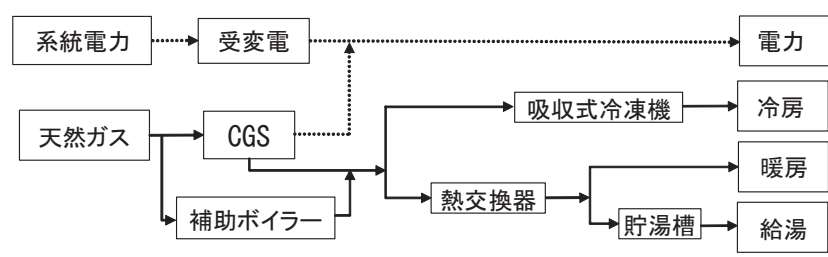

図 7 提案システムのフロー

CGS 等の設備初期投資に関しては、安芸ら ${ }^{12)}$ の研究により表 3 に 転記する。但し、CGS 導入規模による初期投資は異なるとする ${ }^{15)}$ 。 また、 2 年目からの稼動費用は 1 年目と同様、発電設備のライフサ イクルを 15 年と設定する。CGS の各種パラメーター設定值及び適用 した上海市のエネルギー料金 ${ }^{12}$ は表 3 に示す。

以上の分析に基づいて、重回帰分析法により、CGS の発電容量、 発電機の効率、部分負荷、台数及び燃料単価の増減等を評価項目と し、省エネルギー率への影響因子の感度分析を行う。

\section{2 システム設定}

提案システムのフローは図 7 に示す。一般電力は系統電力及び CGS の発電により賄われる。排熱は熱交換器 $(\mathrm{COP}=1.0)$ 、吸収式冷凍機 $(\mathrm{COP}=1.1)$ を用いて、熱、給湯、冷熱を供給し、熱需要の不足分は 追加した補助ボイラー（効率 80\%）により賄われる。 


\section{3 運転形態の設定}

負荷変動の特性分析結果から見ると、熱需要の総量が一般電力需 要をかなり超えている。熱負荷の変動に追従して発電する熱主電従 運転（熱負荷追従運転）方式は回収される排熱が熱負荷にほぼ等し くなるように運転されるため、一般にエネルギー効率の高い運転と 言えるが、実際は制限が困難である。また、中国では現在、逆潮流 による売電は実現できていないことも考え、電力負荷の変動に追従 して発電し、回収された排熱を出来るだけ利用した上、余った時は 放熱する方式である電主熱従運転（逆潮流なし）を選定する。

\section{4 制約条件の設定}

本論では、図 6 の中間に示すように、三つの制約条件を課す。 まず、一般に CGS は負荷率の低下に伴い発電効率が低下され、一 定の負荷率以下では運転が行われない。石田ら ${ }^{16)}$ の研究により、定 式化された CGS の部分負荷効率を用いて、部分負荷により発電効率 の低下を考慮する。詳細は注 ${ }^{1)}$ を参照する。CGS の発電量が CGS 発 電容量の $30 \%$ より低い場合、運転しないとする。

その次、経済性から考えて、系統電力から買電のコストが CGS 発 電コストより低い場合、系統電力からの買電を優先とする。

最後に、電主熱従運転（逆潮流なし）の場合、系統電力からコン スタントに一定量（最低買電量）を受電する必要があるので、本論 ではこの最低買電量を複合施設の一般電力需要量のピークの $10 \%$ と する。

\section{4. 省エネルギ一性の影響因子分析}

省エネルギーに影響する因子は数多くあるが、本論では CGS 導入 容量の規模、発電機の発電効率・熱回収効率、台数、燃料単価増減 を評価項目とし、且つ独立因子で省エネルギー率との関係を求め、 それらの因子の省エネルギー性への影響を分析する。また、重回帰 分析により評価視点に最も関係のある主要な因子を選択する。

\section{1 CGS 導入容量（規模）と省エネルギ一性}

図 8 に発電効率と熱回収効率をそれぞれ $30 \% 、 45 \%$ と設定した場合 の電力需要量のピーク值当たり CGS の導入容量と省エネルギー率の 関係を示す。図から CGS 原動機の導入容量が電力需要量のピーク値 (9470 kW) の 10\%から 100\%まで変化させ、導入規模の増加につれ、 省エネルギー率が上がることが分かる。その原因として、当該ビル ではホテルを含めた建物の熱需要が図 5 のように非常に高く、電力 需要を大きく超えているので、CGS 発電による排熱量がほとんど利 用されているものだと考えられる。ただし、一定の規模に達してか ら、規模が増加することに対して、省エネルギー率の増加率は緩や かになっている。例えば、電力需要のピーク值の $60 \%$ CGS で賄わ れる場合に比べ、 $100 \% \mathrm{CGS}$ により満たされる場合の省エネルギー率 の変化は $2 \%$ 程度しかない。また CGS の容量が大きくなると、排熱が 十分に使いきれなくなり、システムの初期投資が増える恐れがある ため、適切な容量の決定が望ましい。そこで、定量的に経済性効果 を需要家に提示する意味を持つライフサイクルコストを計算する。 その結果は図 8 の棒グラフに示す。ライフサイクルコストが最も低 いケースは電力需要量のピーク值の $60 \%$ でる。従って、省エネル ギー且つ経済効果の視点から、電力需要のピークの 6 割程度を CGS により賄われることが妥当であると考え、以下の他の因子分析では

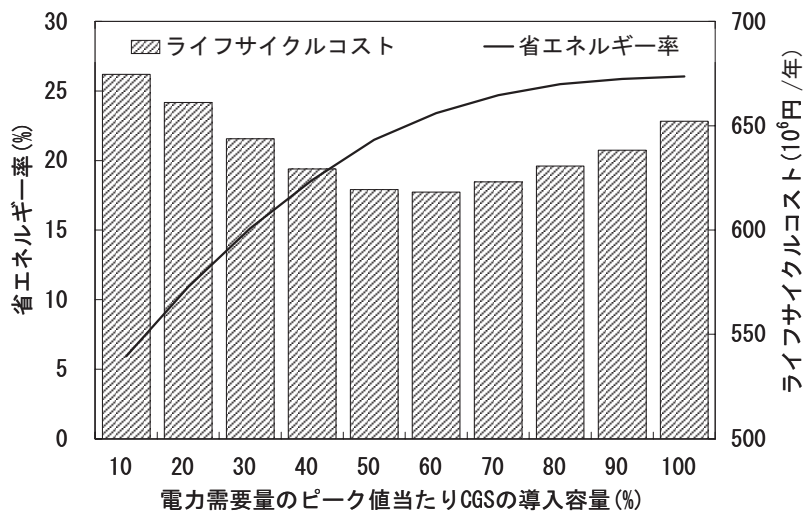

図 8 CGS の導入容量と省エネルギー性及び経済性の関係

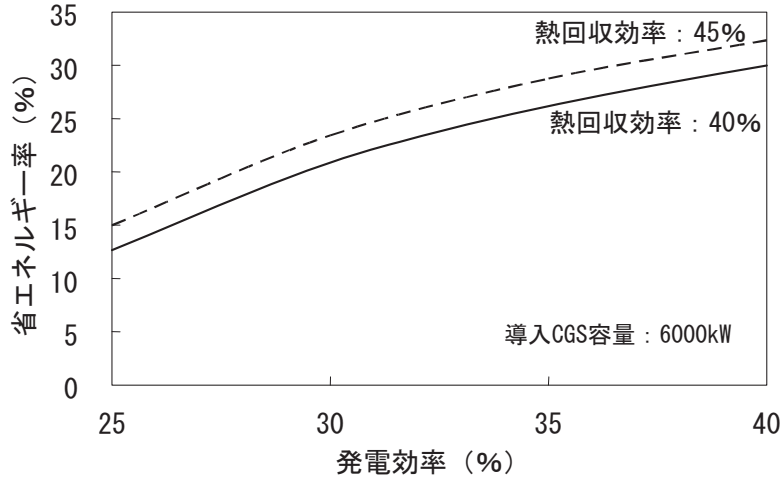

図 9 CGS 発電効率と省エネルギー性

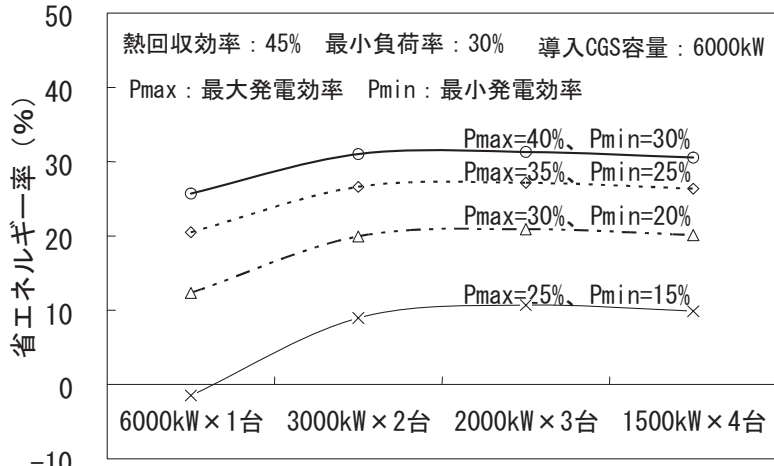

図 10 台数制御と省エネルギー性

CGS の容量を 6 割に近く $6000 \mathrm{~kW}$ とする。

\section{2 CGS の効率と省エネルギ一性}

CGS の効率に関しては、定格熱回収効率を 40\%と 45\%に、定格発電 効率を $25 \%$ から $40 \%$ まで変化させ、CGS の発電効率及び熱回収効率の 省エネルギー性への影響度を分析し、その結果を図 9 に示す。導入 CGS の発電容量は前節に述べたように、6000 kW とする。計算結果か ら、熱回収効率に比べ、発電効率が省エネルギー性に与える影響は より大きい。例えば、同じ熱回収効率の場合、CGS の発電効率を $30 \%$ から $35 \%$ まで変化させると、省エネルギー率の増加割合が約 $8 \%$ 以上 になる。一方、同じ発電効率の場合、熱回収効率を40\%から $45 \%$ まで 増加しても、エネルギー率の増加割合が約 $2 \%$ にどまっている。CGS の技術革新は発電効率の向上に重点を置くべきである。

\section{3 台数と省エネルギ一性}

ここでは、前節と同様に、CGS 導入の発電容量は $6000 \mathrm{~kW}$ とし、 
定格熱回収効率 $(45 \%)$ 、定格発電効率を $25 \%$ から 40\%までに変化させ る場合、CGS の導入台数と省エネルギー率の関係を検討する。その 結果は図 10 に示す。ここでの最大発電効率（Pmax）は、負荷率 100\% 時の発電効率 (定格発電効率) であり、最小発電効率 $(\mathrm{Pmin})$ は、負 荷率 30\%時の発電効率である。部分負荷を考慮する場合、実際の負 荷率に当たる各々の発電効率は注 ${ }^{1)}$ の式 4 より求める。なお、負荷 率が 30\%以下になると、CGS のシステムが稼動しないと仮定する。図 10 から、台数制御は省エネルギー性に影響を与えることが分かる。 例えば、 $6000 \mathrm{~kW} \times 1$ 台の場合、いずれも省エネルギー率が低く、発 電効率が $25 \%$ 以下になると、既存システムよりもエネルギー消費量 が増えているため、省エネルギー率がマイナスになる。一方、2000 kW $\times 3$ 台の省エネルギー率が最も高く、次に $1500 \mathrm{~kW} \times 4$ 台と $3000 \mathrm{~kW}$ $\times 2$ 台の順となっている。省エネルギ性から、CGS の妥当な台数は $2000 \mathrm{~kW} \times 3$ 台であると考えられる。

\section{4 燃料単価増減と省エネルギ一性}

次に、発電容量 $2000 \mathrm{~kW}$ 台数 3 台の CGS を導入する場合、燃料料 金(電気・ガス)の増減による省エネルギー率の変化を検討する。こ こでは、定格発電効率は $35 \%$ 、定格熱回収効率は $45 \%$ とする。図 11 は燃料料金の変化につれ、CGS 運転費用を最小にする 3 台の平均運 転時間の積算值を示す。ガス料金が-60\%から 140\%まで変化させ、電 力料金の倍増、半減の 2 ケースを加え、燃料料金の省エネルギー率 への影響度を検討寸る。計算結果から、現行料金での 3 台 CGS の平 均運転時間は 6008 時間であることが分かる。

全体として、ガス料金が上がると、運転時間が減り、CGS の競争 力が低くなる。逆にガス料金が下がると、運転時間が上がり、CGS の普及に有利である。また、電力料金が倍増すると、運転時時間も 上がり、ガス料金が上がるとしても、CGS の運転時間が長いことが 見られる。これは石油高騰により、将来電力とガス料金が共に増加 する場合でも、CGS 普及の市場があることを意味する。

燃料料金の増減による省エネルギー率の変化を図 12 に示す。現行 料金での省エネルギー率は 29.94\%となる。また、燃料料金の同時増 加による省エネルギー率は現行料金の省エネルギー率とほぼ同様と なっていることから、燃料料金増の場合でも、地球温暖化を軽減す るためには、CGS を積極的に導入すべきであると考える。

\section{5 エネルギー収}

今まで、CGS の規模、発電効率及び台数等について検討してきた が、ここでは、省エネルギー性への影響原因を調べるために、電力 及び熱の消費バランスを検討する。CGS の発電容量は $2000 \mathrm{~kW} の 3$ 台で $6000 \mathrm{~kW}$ 、定格発電効率は 35\%、定格熱回収効率は 45\% とする。

図 13 と図 14 に現行料金の下で計算した時刻別エネルギー収支の 積算曲線を示す。図 13 は電力供給と需要のバランスを示している。 CGS の発電容量が $2000 \mathrm{~kW}$ である原動機が一般電力負荷に合わせて 1 台から 3 台まで運転する。発電機の全負荷運転と部分負荷運転の時 間及び系統電力からの買電量等を図 13 に示す。例えば、 1 台目の場 合、全負荷運転時 (負荷率 $=100 \%$ ) と部分負荷運転時 (負荷率 $<100 \%$ ) の発電量はそれぞれ約 13.8 GWh と $1.6 \mathrm{GWh}$ である。一台目の CGS 運転時間を見ると、全負荷での運転時間は $6917 \mathrm{~h}$ であり、年間 8 割を占める。1 台目の停止時間は $889 \mathrm{~h}$ となっている。これは、約 束条件として経済的な運転及び最低買電量を考慮する場合、夜間で
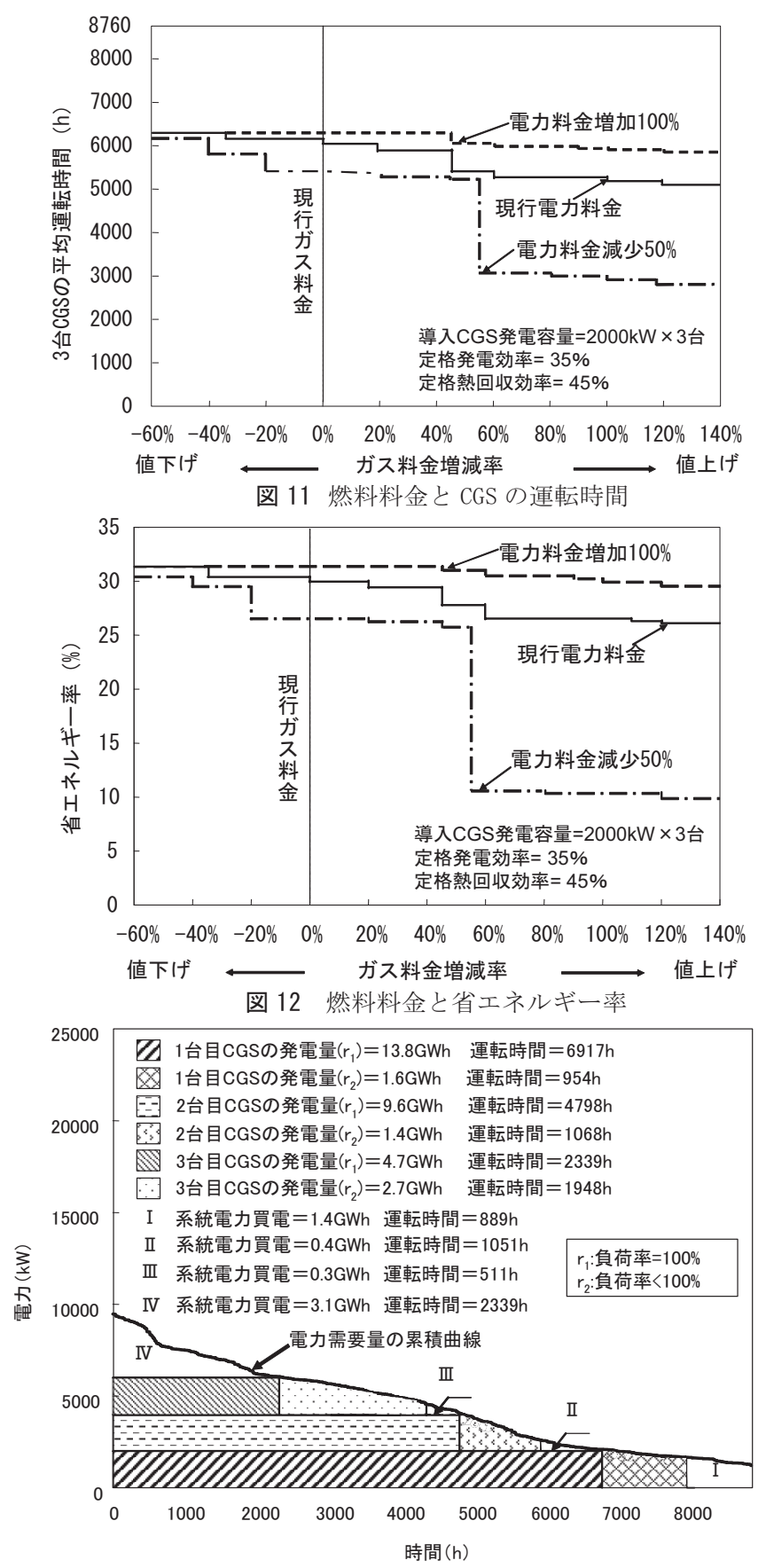

図 13 一般電力需要累積曲線及び利用状況

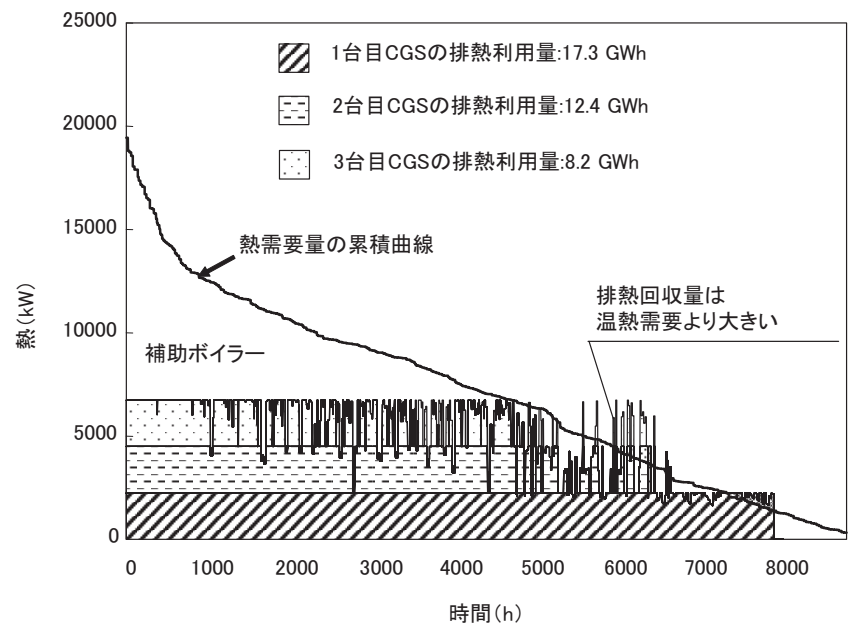

図 14 熱需要累積曲線及び利用状況 
は系統電力の買電が優先された為である。一方、2 台目の全負荷運 転時の運転時間は 1 台目より $30 \%$ 少なく、約 $4,800 \mathrm{~h}$ となっている。 全負荷運転の発電量は $9.6 \mathrm{GWh}$ 、部分負荷運転の発電量は $1.4 \mathrm{GWh}$ で ある。3 台目では、全負荷と部分負荷の運転時はほぼ同様であり、 全負荷運転下の発電量 $(4.7 \mathrm{GWh})$ は部分負荷の $(2.7 \mathrm{GWh})$ より若干高 く占めている。CGS による発電量の総計と年間電力需要量を除算し たものを CGS 依存率(電力）とし ${ }^{17) 、}$ 、計算を行ったところ、83\%であ る。CGS システムへの依存度が非常に高いことが分かる。

図 14 は、CGS 台数ごとの排熱量、排熱利用量、補助ボイラーの熱 供給量等を計算したものである。CGS から回収された熱(排熱回収 量)のうち、空調、暖房及び給湯等に有効に利用された熱(排熱利用 量）の比率は排熱利用率といい ${ }^{17)}$ 、計算の結果により、排熱利用率 が 90\%を上回り、顕著に高いと言える。当ビルの熱需要量が非常に 高く、選定された発電機の容量は電力需要ピークの 6 割であったた め、発生した排熱量はほぼ全部利用され、不足部分は補助ボイラー により賄う。図 13 に比較すると、白い部分(補助ボイラーによる熱 量）の面積がより大きいことが分かる。実際排熱回収量が熱需要を 越える部分は図 14 の右のわずか時間だった。

最後に CGS から出力された発電量と排熱利用量を燃料消費量 (投 入エネルギー)で割り、CGS システムの総合効率を求めた結果、約 $80 \%$ となり、システムとして無駄の少ない運転ができているといえる。

\section{6 総合評価}

ここで、重回帰分析法を用い18)、省エネルギー率を目的変数とし、 評価項目を説明変数とし、省エネルギー性の影響因子の重みを分析 する。表 4 にその結果を示す。影響因子の標準偏回帰係数を見ると、 発電効率 (技術) 影響度合いが最も大きく、次に電気料金、CGS 容量 (規模)、台数等の順になっている。

従って、CGS を導入する際には、まずCGS 技術の進展を十分に検 討した上、市場の燃料料金及び対象の負荷特性を考慮した適切な規 模を選択し、計画することが肝要であると考えられる。

\section{5. 結論}

本研究では、中国ではまだ CGS の導入が遅れている中、ホテルや オフィスを有する上海の複合施設 JM ビルを研究対象とし、2006 年 の実測データを用い、各種エネルギー消費状況を解析し、CGS の導 入による省エネルギー性を明らかにした。以下に本研究で得られた 知見を示寸。

（1) 当複合施設は年間を通して安定した電力・熱負荷が発生し、電 力負荷と熱負荷の時刻別発生パターンが類似している。また熱 需要量が一般電力需要量を大幅に上回り、年間の熱電比の平均 值は 1.55 で、熱電比が比較的高いと言える。

(2) 熱需要の高い対象ビルでは、電主熱従の CGS 運転方式では、導 入規模 (発電容量) の増加につれ、省エネルギー性も増加して いくが、一定の規模に達してから、規模の増加に対して、省エ ネルギー率の増加は緩やかになってくる。本研究対象では、経 済性及び省エネルギー性の視点から、妥当的な CGS 導入発電容 量は一般電力需要のピークの 6 割程度で $6000 \mathrm{~kW}$ だと判明した。

(3) CGS の発電効率及び熱回収効率が同時に省エネルギー性にとっ て重要な因子だが、熱回収効率に比べ、発電効率が省エネルギ
表 4 省エネルギー性重要因子特徴

\begin{tabular}{|c|c|c|c|c|c|c|}
\hline 説明変数名 & 偏回帰係数 & 標準偏回帰係数 & F值 & 判定マーク & 偏相関 & 単相関 \\
\hline 発電効率 $(\%)$ & 1.171 & 0.720 & 101.744 & [**] & 0.712 & 0.494 \\
\hline ガス料金の増加率 (\%) & -0.058 & -0.384 & 42.600 & {$[* *]$} & -0.548 & -0.207 \\
\hline 電気料金の増加率 $(\%)$ & 0.086 & 0.377 & 57.563 & {$[* *]$} & 0.606 & 0.382 \\
\hline CGS容量 $(\mathrm{kW})$ & 0.002 & 0.370 & 50.412 & [**] & 0.581 & 0.486 \\
\hline 最小負荷率 $(\%)$ & -0.208 & -0.341 & 9.265 & [**] & -0.293 & -0.010 \\
\hline CGS台数(台) & 2. 327 & 0.265 & 5. 101 & [*] & 0.221 & 0.062 \\
\hline 熱回収効率 $(\%)$ & 0.483 & 0.171 & 11.575 & [**] & 0.324 & 0.016 \\
\hline 定数項 & -52.010 & & & & & \\
\hline \multicolumn{7}{|c|}{ ※2：目的変数（一次エネルギ一削減率 $(\%)$} \\
\hline
\end{tabular}

一性に与える影響はより大きい。CGS の技術革新は発電効率の 向上に重点を置くべきである。

(4) CGS の台数変化も省エネルギー性に影響を与えるが、細かい台数を 増えればよいものではなく、最も省エネルギーの最適解が存在す ることが分かった。本対象では、CGS の発電容量 $2000 \mathrm{~kW} の 3$ 台がもっともよい選択であった。

(5) 全体として、ガス料金が上がると、運転時間が減り、CGS の競 争力が低くなる。逆にガス料金が下がると、運転時間が上がり、 CGS の普及に有利である。また、電力料金が倍増すると、運転 時時間も上がり、ガス料金が上がるとしても、CGS の運転時間 が長くなる。これは石油高騰により、将来電力とガス料金が共 に増加する場合でも、CGS 普及の市場があることを意味する。

(6) 重回帰分析法を用い、省エネルギー性に関する感度分析を行っ た結果として、CGS 発電効率が最も重要な影響因子となり、次 に燃料料金の増加率、CGS 発電容量、CGS 台数の順であり、こ れらの重要因子を考慮して計画し、評価することが肝要である。 本研究により、対象建物において、省エネルギー性の観点だけで はなく、経済的な観点からも、CGS の導入が大きな効果があること を検証できた。今後、当ビルにおける CGS の具体的な導入を促進し、 CGS の設計段階に移すよう、実際の CGS 機器選択等を進めて行きた いと考えている。なお、今後中国における同類の建物について CGS の導入可能性を検討していきたい。

更に、単一ビルだけではなく、地域規模の CGS を導入する立場か らその可能性を探るとともに、配管のレイアウト、設備の設置など を含めた熱源ネットワーク化の計画を策定していくことも望まれる。

\section{謝辞}

本研究は、文部科学省・平成 20 年度基盤研究 B (海外) 20404014 (代 表：高偉俊）によるものである。また、本研究遂行に当たっては上 海金茂ビルの工程技術部ルアン部長、エネルギーセンターの方々か ら実測データ及び貴重な情報を頂き、ここに謝意を表す。

注

注1）一般に、CGS は負荷の低下と共に発電効率が低下し、また、一定の負荷効率以 下での運転は行われない。このような運転特性は現実の機器一般に見られるもの だが、その定式化に以下のような 2 值整数を用いる必要がある。具体的にCGS の 部分負荷効率を定式化する方法として、発電効率 P を求めるために以下の式を用 いる。 $r_{0}$ は発電機の最低負荷率、 $\varepsilon$ は $0 、 1$ 整数であり、最低負荷率が $30 \%$ 以下 になるとシステムが停止すると仮定し、システムの稼動・停止に伴うエネルギー 消費は最低負荷率時の 1 時間当たりの燃料消費量の $1 / 5$ と仮定する ${ }^{16)}$ 。

$\mathrm{r} \leq \varepsilon$ 且 $\supset \mathrm{r} \geq \mathrm{r}_{0} \times \varepsilon \quad(\varepsilon=0,1)$
$\mathrm{P}=\mathrm{P}_{\text {min }}+\left(\mathrm{r}-\mathrm{r}_{0}\right) \times\left(\frac{\mathrm{P}_{\text {max }}-\mathrm{P}_{\text {min }}}{1-\mathrm{r}_{0}}\right)$ 
ここでは、 $\mathrm{P}=$ 発電効率

Pmin=発電効率の最小值

$P \max =$ 発電効率の最大值

$\mathrm{r}=$ 負荷率 $\mathrm{r}_{0}=$ 最小負荷率

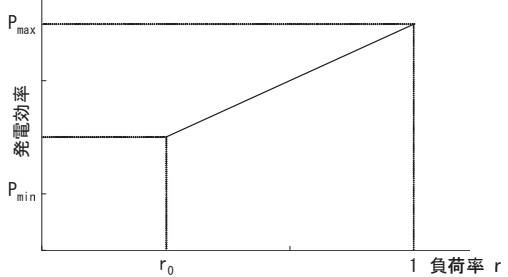

図 15 CGS の部分負荷特性の定式化

\section{参考文献}

1）湯浅俊昭，CHEW CHONG SIANG，川原田抄苗：中国天然ガス政策の現状と 展望〜「西気東輸」 1 を中心に〜, 国際協カプロジェクト部・日本エネル ギー経済研究所, IEEJ, 2003.2

2）高偉俊, 李海峰他：電源開発株式会社委託調查「上海地域における省工 ネルギーの現状及び ESCO 事業の参入可能性に関する調查業務」，有限会社 ジオ・クラスター, 2005.12

3）市川徹, 佐土原聡, 尾島俊雄 : 首都圈の大規模住宅団地におけるコージェ禅 レーショシシステム導入の可能性に関する研究, 日本建築学会計画系論文報告集, No. 427 , pp. $29-38,1991.9$

4）三瀬農士，佐藤春樹：慶應義塾大学湘南藤沢キャンパスにおけるコージェ齐 レーションシステムの省エネルギー性および環境性評価, 日本建築学会環境系論文 集，No. $616 ， p p .51-58,2007.6$

5）村上公哉他：集合住宅と高齢者福祉施設の複合建物におけるコージェネレージ 脑不㕕の効果に関する研究, 日本建築学会大会学術講演梗概集, D-1 分冊, pp. $997,2002.8$

6) 岡建雄他：CGS を導入した病院施設のライフサイクル評価とコミッショ ニングのり方に関する研究, 日本建築学会大会学術講演梗概集, D-2 分冊, pp. $1181,2002.8$
7）佐土原聡他：CGS を拠点とした小規模地域熱供給のあり方に関する研究, 日本建築学会大会学術講演梗概集，D-1 分冊，pp. 523，2003.8

8）村上公哉他：都市における分散型エネルギー供給システムの導入促進に 関する研究, 日本建築学会大会学術講演梗概集, D-1 分冊, pp. 561, 2003.8

9）柳井崇他 : 既存街区におけるコージェ礼・ションシ人テム導入によるエネルギーの面 的利用に関する研究日本建築学会大会学術講演梗概集, D-1 分冊, pp. 907, 2007. 8

10）内山洋司，萩原啓太：エネルギーチェーン多層評価システムを用いた分 散型電源の環境影響分析, エネルギー・資源学会, 第 22 回エネルギーシス テム・経済・環境コンファレンス講演論文集，pp.199-202，2006.1

11）岡田和宏, 加藤丈佳, Wu Kai, 䆶田光宏, 鈴置保雄 : 中国産業都市にお ける次世代エネルギーシステム評価モデル構築に関する基礎的検討, 電気 関係学会東海支部連合大会，講演論文集，No. 500，pp. 344，2002.9

12）安芸裕久, 村田晃伸：中国都市部における民生ビルーのガスコジェ祙シショソ 導入に関する検討，第 21 回エネルギーシステム・経済・環境コンファレン ス，エネルギー資源通巻，Vol. 26， No. 3， pp. 225-228，2005.1

13）阮応君, 高偉俊 : Optimization of co-generation system for housing complex-Housing complex's scale and system's operating mode, 日本建 築学会環境系論文集, No. 592，pp. 15-22，2005.6

14）原英嗣，高偉俊，尾島俊雄：事務所建築における空調設備の保全費予測 と更新時期の評価手法に関する研究，日本建築学会計画系論文集， No. 547 , pp. 209-214，2001.9

15）（社）日本ガス協会

http://esd.env.kitakyu-u.ac.jp/weijun/lesson/2003/2003under1/chapter6/6-6.ht m (参照 2008-11-14)

16）石田武志, 森俊介, 堂脇清志: 経済制約と機器の部分負荷特性を考慮した 業務建物の最適 CGS 導入決定支援システムの構築, 電気学会論文誌 B 部門, Vol. 125, No. 4, pp. 373-380, 2005.4

17）日本コージェネレーション編: コージェネレーション総合マニュアル (2003)

18）韋新東: 地域冷暖房の評価手法に関する研究, 日本建築学会計画系論文集, No. 537 , pp. $71-76,2000.11$

(2008年 7 月 9 日原稿受理，2009年 2 月 25 日採用決定） 